\title{
Towards a Profitable Pricing Strategy for Rural Women Indigenous Chicken Breeders: A Case of Rural
} Village in Zimbabwe

\author{
Gwendoline Vusumuzi Nani ${ }^{1} \&$ Casper Ronney² \\ ${ }^{1}$ Graduate School of Business, National University of Science and Technology, Zimbabwe \\ ${ }^{2}$ Girls College, Zimbabwe \\ gwendoline.nani@nust.ac.zw,gweni.nani@gmail.com, casperronney@gmail.com
}

\begin{abstract}
Indigenous chickens contribute towards poverty reduction, income generation and economic empowerment of rural women. In this regard, employment of a profitable pricing strategy in selling the indigenous chickens becomes fundamental. This study sought to find out the pricing strategies used by rural women indigenous chicken breeders in one purposively selected village in Zimbabwe. An interpretivist paradigm, a qualitative approach and a case study design were employed to examine the issue under review. Seventeen rural women indigenous chicken breeders were key informants. Data collected using semi structured questionnaires and face to face interviews was analysed to discern themes. Results revealed that rural women indigenous chicken breeders did not apply any pricing strategies when selling their chickens. Prices were approximated based on mainly the weight of the chickens. The study concluded that rural women indigenous chicken breeders were ignorant of pricing strategies and factors to consider when determining, prices for their chickens. Further to that, ignorance of appropriate pricing strategies exposed rural women indigenous chicken breeders to exploitation and loss of revenue. In light of this, the study recommended that workshops be conducted by personnel with an accounting background, to train rural women indigenous chicken breeders on the factors to consider in determining profitable prices for their indigenous chickens. The contribution of this study lies in the development of a framework of factors which rural women indigenous chicken breeders could use as a reference point when determining prices for their indigenous chickens.
\end{abstract}

Keywords: Costs, indigenous chickens, pricing strategies, profit, rural women.

\section{Introduction and Background}

Indigenous chickens form the largest poultry flock in Africa and they are found in almost every homestead. In Asia, China, Thailand and Taiwan, they are not only kept for home consumption but to enhance food security and improve household incomes (Ouma, 2011). Indigenous chickens which are commonly referred to as village or organic or free-range chickens make an immense contribution to poverty reduction, food security and income generation (TAN, 2013; Alemayehu et al., 2018; Mirembe, 2018). Kingori, Wachira and Tuitoek (2010) concur that indigenous chicken production is a way of increasing rural incomes and economic empowerment of the rural women and youth. Zinyuke (2017) asserts that in Kenya, free-range poultry production has provided "village-based food and income generation opportunities to landless and marginal farmers, especially women," for many years.

According to Maumburudze, Mutambara, Mugabe and Manyumwa (2016), production of organic chickens has always been for consumption purposes. However, there has been an increase in the production of organic chickens for commercialisation purposes. Rukuni, and Eitchel (2006) cited by Maumburudze et al. (2016) define commercialisation as a transition from mostly subsistence agriculture to production for both local and export markets. Commercialisation is increasingly gaining recognition in rural development discourse. Siyaya (2013) concurs that in Swaziland, the indigenous poultry farmers have been encouraged to commercialise in order to improve their livelihoods in terms of food security, poverty alleviation, income generation and as a drive towards self-sufficiency in poultry products. Maumburudze et al. (2016) also agree that indigenous poultry commercialisation in rural households is a potential source of income.

In Zimbabwe, too, according to Zinyuke (2017), there is a growing interest in indigenous foods. In the past five years or so, numerous traditional food eateries have been opened, while hotels have been putting traditional dishes on their menu. Zinyuke (2017), further asserts that while almost every household in the rural areas has always kept free-range chickens for food and a few have sold a bird here and there to raise some money for use in the home, commercial free-range chicken production is a fairly new concept in many 
areas. With the surge in the drive towards commercialisation, the researchers are of the view that there is bound to be an increase in demand for indigenous chickens from rural women chicken breeders. With the assertion that commercial free-range production is a new concept, one wonders whether rural women indigenous chicken breeders are aware of factors to consider in determining prices for indigenous chickens, hence this study. Considering that rearing of indigenous chickens is a source of livelihood for rural women, it is essential to find out the strategies that they use in determining prices for their indigenous chickens, in order to ensure that they enhance their profitability in the event of increased demand. In review of literature on rearing of indigenous chickens, researchers did not access any studies on pricing strategies used by rural women indigenous chicken breeders, so it became paramount to come up with this study so as to bridge this gap in literature.

Statement of the Problem: There has been an increase in the demand for indigenous chickens as healthy dietary consciousness increases. This is confirmed by Sichizuwe (2019), that the market for indigenous poultry continues to rise due to health related feeding preferences which seem to favour consumption of white meats. The increase in demand for indigenous chickens provides a good opportunity for rural women to participate in poultry production to enhance their profits and economic empowerment. However, prices charged by rural women chicken breeders is more of a 'give away' than an income generating activity. Since these rural women indigenous chicken breeders rely on their chickens as a source of revenue, it is important that they are appraised of the factors to consider when determining the prices for their chickens.

Purpose of the Study: This study sought to establish how rural women poultry breeders determined prices for their indigenous chickens. Findings from such a study would serve as major inputs in the development of a pricing framework to capacitate rural women indigenous chicken breeders on profitable pricing strategies. The suggested pricing framework would assist Zimbabwean women who have a historical background of lower educational levels (Kambarami, 2006; UNICEF cited by CSO, 2002). Furthermore, these results would serve as reference material for other chicken breeders and policy makers.

Research Objective: The primary objective of this study was to find out the pricing strategies used by rural women indigenous chicken breeders in one selected village in Zimbabwe.

Secondary Research Objectives: The following secondary research objectives served to fulfil the primary research objective.

- To find out the background of the establishment of indigenous chicken projects for rural women breeders in one selected village in Zimbabwe.

- To determine the operating expenses borne by rural women indigenous chicken breeders in one selected village in Zimbabwe.

- To find out the challenges faced by rural women indigenous chicken breeders in running their projects in one selected village in Zimbabwe.

- To develop a pricing strategy framework to capacitate rural women indigenous chicken breeders.

\section{Literature Review}

The primary purpose of keeping village chickens is to earn revenue (Phiri, 2017). According to McAinsh, Kusina, Madsen \& Nyoni (2004), poultry production has shown to be a very important income generating activity, predominantly run by women. Income generated from chicken production is spent to better nutrition, health and education of the family. Padhi (2016); Alemayehu et al. (2018) \& Mirembe (2018) concur that indigenous breeds of chickens are the mainstay of livelihoods of most rural households in developing and underdeveloped countries. They play a major role for the rural poor and marginalised section of the people with respect to their subsidiary income. Mapiye, Mwale, Mupangwa, Chimonyo, Foti and Mutenje (2008) allude to the view that the development of village chicken production can be a sustainable way of helping to meet the welfare needs of rural populations and raise their standard of living. Alemayehu et al. (2018) support the views that chicken production is a valuable asset to the local population especially for the disadvantaged groups and less favoured areas of rural Africa and elsewhere in the developed world. Chicken production contributes to food security, poverty alleviation and the promotion of gender equality. 
According to Kingori et al. (2010), indigenous chickens get most of their feed from scavenging and many occasionally benefit from chicken and other household wastes. Siyaya (2013) concurs that in the past, chickens were exposed to scavenging systems for feed and had minimal supplementary feed. There was no provision for housing, thus they were characterised by low input and low output. Zinyuke (2017) agrees that free range chickens can feed on a normal diet of grass, worms and bugs as they are allowed to freely roam about. However, Kingori et al. (2010), point out that productivity of indigenous chickens that rely on scavenging only is low due to factors which include poor nutrition, diseases and management. Therefore, feed supplementation, provision of housing and disease control in indigenous chickens, can improve the growth rate and egg production. In a study by Maumburudze et al. (2016) on the commercialisation of indigenous chickens in Makoni District, Zimbabwe, farmers argued that supplementary feeding significantly enhanced the growth rate of free-range chickens especially when coupled with the use of modern medicines. However, rural households may not fully comprehend or possess the required business acumen to negotiate with traders and middlemen.

Phiri (2017) asserts that although chicken rearing contributes to the income of rural households, production of indigenous chickens has challenges. These challenges have led to low gains. Challenges include the need for vaccinations, proper housing units, organised markets and provision of supplementary feed. Dube, Francis \& Maliwichi (2016) share similar sentiments that besides the aforesaid challenges, lack of regulation of prices of poultry feeds makes it difficult to run profitable poultry business. High prices of poultry feeds force poverty alleviation programmes, 'PAPs,' to have fewer chickens than what is required for optimal performance. Besides, the cost of poultry feeds, these chickens have to be vaccinated against diseases and Dube et al. (2016), assert that drugs and vaccines for poultry are expensive.

Initiatives to improve output have cost implications which have to be considered when determining a price. According to the Cambridge Advanced Learner's Dictionary (2008:315), cost refers to the amount of money needed to buy, do or make something. Price is the amount of money for which something is sold (Cambridge Advanced Learner's Dictionary 2008:1124). Horngren et al (1997) asserted that when coming up with a selling price; direct material, direct expenses, variable overheads, fixed overheads and mark-up should be considered. Costs that are traced to objects are direct costs, and costs that are allocated to a cost object are indirect costs. Based on Horngren et al (1997)'s explanation, even if rural women poultry breeders use their own children in rearing these chickens, this constitutes indirect costs and should be considered. Chase (2008) cited by Siyaya (2013) asserts that products are generally priced based on customers' demand, competition and costs. Most farmers use the cost based strategy which is the strategy that determines profit based on cost (production and transaction costs). Siyaya (2013) posits that profitability is the measure of the returns a business creates after deducting operating costs and other expenses from income divided by inputs.

It is important to explain why the study focused on rural women indigenous chicken breeders. According to McAinsh et al. (2004) \& Alemayehu et al. (2018), a large number of women in the households often with the assistance of children are actively involved in the production of chickens which helps them to generate revenue and/ or complement the nutrition requirements of the family. Historically, women in Zimbabwe were marginalised educationally (Kambarami, 2006; UNICEF cited by CSO, 2002). Although the historical marginalisation of women is beyond the scope of this paper, it is important to consider this educational background for contextualisation purposes of the study.

\section{Methodology}

The study which adopted an interpretive paradigm and a qualitative approach was conducted in one purposively selected village in Zimbabwe. The target population for the study was 17 rural women indigenous chicken breeders thus constituting 17 households. The snowball sampling technique was used to identify the participants where one identified rural woman indigenous breeder referred the researchers to other key informants with similar characteristics (Cooper and Schindler, 2008). The justification for having women as key participants was informed by Alemayehu et al. (2018) that the routine management of poultry was undertaken by women, often with the assistance of children. Data collection instruments included face to face interviews and semi-structured questionnaires. Regarding ethical issues, permission to conduct the study was sought from the relevant authorities and it was granted. Verbal consent had to be sought from 
'would be' participants before the commencement of the interviews. The researchers ensured that protection from harm, confidentiality and anonymity of the participants were observed.

\section{Results and Discussion}

The study sought to find out the pricing strategies used by rural women indigenous chicken breeders in one selected rural village in Zimbabwe. Results and discussions are based on the objectives of the study in which 17 participants were key informants.

Background of the Establishment of Indigenous Chicken Projects by Rural Women: Table 1 shows the background details of the establishment of indigenous chicken projects by rural women in terms of: their duration in the indigenous chicken industry, the number of chickens they bred, the source of the chickens and the costs of start-up chickens.

Table 1: Shows Background Details of the Establishment of the Chicken Projects for Rural Women Indigenous Chicken Breeders

\begin{tabular}{|c|c|c|c|c|}
\hline Participant & Question 1 & Question 2 & Question 3 & Question 4 \\
\hline & $\begin{array}{l}\text { How long have you } \\
\text { been in the } \\
\text { industry? }\end{array}$ & $\begin{array}{l}\text { How many chickens do } \\
\text { you have? }\end{array}$ & $\begin{array}{l}\text { What was the } \\
\text { source of your } \\
\text { chickens? }\end{array}$ & $\begin{array}{l}\text { If you bought them, } \\
\text { how much did each } \\
\text { chick cost you? }\end{array}$ \\
\hline 1 & two years & 10 chickens & I bred them & $\mathrm{N} / \mathrm{A}$ \\
\hline 2 & 20 years & 30 chickens & I bred them & $\mathrm{N} / \mathrm{A}$ \\
\hline 3 & 20 years & 13 chickens & I bred them & $\mathrm{N} / \mathrm{A}$ \\
\hline 4 & two years & 20 chickens & I bought them & 15 RTGS each \\
\hline 5 & two years & 18 chickens & I bred them & $\mathrm{N} / \mathrm{A}$ \\
\hline 6 & 50 years & 20 chickens & I bred them & $\mathrm{N} / \mathrm{A}$ \\
\hline 7 & 50 years & $\begin{array}{l}30 \text { chickens and } 14 \\
\text { chicks }\end{array}$ & I bred them & $\mathrm{N} / \mathrm{A}$ \\
\hline 8 & five years & seven chickens & I bred them & $\mathrm{N} / \mathrm{A}$ \\
\hline 9 & two months & 10 chickens & I bred them & N/A \\
\hline 10 & 20 years & $\begin{array}{l}\text { five chickens and } 12 \\
\text { chicks }\end{array}$ & I bought them & 10 RTGS each \\
\hline 11 & three years & 25 chickens & I bred them & $\mathrm{N} / \mathrm{A}$ \\
\hline 12 & 15 years & 25 chickens & I bred them & $\mathrm{N} / \mathrm{A}$ \\
\hline 13 & five years & 15 chickens & I bought them & 10 RTGS each \\
\hline 14 & It's my first time. & 10 chickens & I bred them & N/A \\
\hline 15 & one year & 56 chickens & I bred them & $\mathrm{N} / \mathrm{A}$ \\
\hline 16 & two years & 20 chickens & I bred them & $\mathrm{N} / \mathrm{A}$ \\
\hline 17 & 15 years & 29 chickens & I bred them & $\mathrm{N} / \mathrm{A}$ \\
\hline
\end{tabular}

Results in Table 1 show that the majority of the participants have been rearing indigenous chickens for a long time, with some having been in the business for fifty years. Rearing of these chickens is on a smaller scale except one participant, who is only one year old in business with 56 chickens. The implication is that these indigenous chickens are mainly for subsistence. These results tally with views expressed by Zinyuke (2017) that commercial free-range chicken production is a fairly new concept in many areas. Based on these findings, the concept of commercialisation could be non-existent. Pertaining to the source of their chickens, only three participants indicated that they had bought them while the rest had bred their chickens, suggesting low startup costs.

Expenses Borne by Rural Women Indigenous Chicken Breeders: Questions in this section related to the type of feed the chickens were given, the source and amount of feed in order to determine the costs incurred. Responses are shown in Table 2, 3 and 4 respectively. 
Table 2: Shows Expenses Borne by the Rural Women Indigenous Chicken Breeders

\begin{tabular}{|c|c|c|c|c|}
\hline Participant & Question 5 & Question 6 & Question 7 & Question 8 \\
\hline & $\begin{array}{l}\text { What do you feed these } \\
\text { chickens on? }\end{array}$ & $\begin{array}{l}\text { Where do you get } \\
\text { your feeds from? }\end{array}$ & $\begin{array}{l}\text { How much is a bag } \\
\text { of feed? }\end{array}$ & $\begin{array}{l}\text { How many bags do } \\
\text { you buy to fully } \\
\text { grow your chickens? }\end{array}$ \\
\hline 1 & sorghum and maize & $\begin{array}{l}\text { I buy the feed from } \\
\text { Bulawayo. }\end{array}$ & $\begin{array}{l}\text { Prices are never } \\
\text { fixed. }\end{array}$ & $\begin{array}{l}\text { sorghum- } 20 \mathrm{~kg} \\
(21 / 2 \text { buckets }) \\
\text { maize-50kg } \\
\text { buckets) }\end{array}$ \\
\hline 2 & $\begin{array}{l}\text { chick mash, rapoko and } \\
\text { maize }\end{array}$ & $\begin{array}{lr}\text { I buy from } & \text { my } \\
\text { neighbours } & \text { and } \\
\text { sometimes } & \text { from } \\
\text { Bulawayo. } & \end{array}$ & $\begin{array}{l}\text { All the prices have } \\
\text { fluctuated. } \\
10 \mathrm{~kg} \text { chick mash } \\
\text { used to be } \$ 50 \\
\text { RTGS. }\end{array}$ & $\begin{array}{l}1 \times 10 \text { kg chick mash } \\
2 \text { buckets rapoko } \\
\text { after } 3 \text { months }\end{array}$ \\
\hline 3 & $\begin{array}{l}\text { rapoko, crushed maize, } \\
\text { sunflower }\end{array}$ & $\begin{array}{l}\text { I grow most of my } \\
\text { feed. }\end{array}$ & $\begin{array}{l}\text { I only buy maize } \\
\text { seed. It used to be } \\
50 \text { RTGS per } 10 \mathrm{~kg} \\
\text { sunflower- } 15 \text { RTGS } \\
\text { per } 2 \mathrm{~kg} \\
\text { sorghum } 5 \text { RTGS per } \\
\text { bag. }\end{array}$ & 4-50 kg bags \\
\hline 4 & crushed maize & $\begin{array}{l}\text { I buy from my } \\
\text { neighbours. }\end{array}$ & 10 RTGS a bucket & 6-60 kg bags \\
\hline 5 & chick mash \& rapoko & Bulawayo & 50 RTGS & $4-50 \mathrm{~kg}$ bags \\
\hline 6 & $\begin{array}{l}\text { rapoko and crushed } \\
\text { maize }\end{array}$ & $\begin{array}{l}\text { I buy rapoko from } \\
\text { neighbours and I } \\
\text { grow my own maize. }\end{array}$ & $\begin{array}{l}\text { I only buy little } \\
\text { rapoko at } 10 \text { RTGS } \\
\text { a tin. }\end{array}$ & $\begin{array}{l}3-50 \text { kg bags, } \\
\text { depending on the } \\
\text { feed }\end{array}$ \\
\hline 7 & chick mash and rapoko & Bulawayo & 150 RTGS & $\begin{array}{l}3-50 \text { kg bags, } \\
\text { depending on the } \\
\text { number }\end{array}$ \\
\hline 8 & chick mash and rapoko & Bulawayo & $\begin{array}{l}70 \text { RTGS for a } 50 \mathrm{~kg} \\
\text { bag }\end{array}$ & 3- $50 \mathrm{~kg}$ bags \\
\hline 9 & rapoko and sadza & Mines & 70 RTGS & 3-50kg bags \\
\hline 10 & rapoko and sadza & Bulawayo & 50 RTGS & $3-50 \mathrm{~kg}$ bags \\
\hline 11 & rapoko and maize & $\begin{array}{l}\text { Anyone who will be } \\
\text { selling }\end{array}$ & 280 RTGS & 1- $50-\mathrm{kg}$ bag \\
\hline 12 & Rapoko & From neighbours & 100 RTGS & $1-50 \mathrm{~kg}$ bag \\
\hline 13 & $\begin{array}{l}\text { I feed chicks on rapoko } \\
\text { and chickens on maize }\end{array}$ & $\begin{array}{l}\text { I grow my own } \\
\text { feeds. }\end{array}$ & N/A & 2 -50kg bags \\
\hline 14 & Rapoko & Bulawayo & 50 RTGS & 2- $50 \mathrm{~kg}$ bags \\
\hline 15 & rapoko and sorghum & Gwanda & 50 RTGS & 2- $50 \mathrm{~kg}$ bags \\
\hline 16 & Maize & Locals & 60 RTGS & 2-50kg bags \\
\hline 17 & rapoko and chick mash & Bulawayo & 300 RTGS & 3-50kg bags \\
\hline
\end{tabular}

According to Table 2, the indigenous chickens are mainly fed on rapoko, maize, and sorghum thus confirming findings by Zinyuke (2017). These are indigenous crops which rural women indigenous breeders can grow to cut down on costs as rapoko and sorghum are drought resistant crops. However, the introduction of chick mash bought from Gwanda and Bulawayo was likely to increase the costs as expressed in their answers. Participant 1, "Prices are never fixed." Participant 2, "Prices fluctuate. This is true of the situation prevailing in the country which has a negative impact on their businesses. These findings corroborate sentiments by Dube et al. (2016) that lack of regulation of prices of poultry feeds makes it difficult to run profitable poultry businesses. This means an increase in the direct costs of producing these chickens should be factored in when determining the prices of chickens. Interestingly, there were two participants who indicated that they grow their own feeds. These participants would be expected to benefit from reduced costs. 
The number of bags required to fully grow the chickens is determined by the number of chickens kept. Although the number of bags to fully grow the chickens were few, the costs were increased by the ever escalating stock-feed prices. If these indigenous chickens were left to scavenge as noted by Kingori et al. (2010); Siyaya (2013) \& Zinyuke (2017), perhaps costs would be very low but nowadays they have to be fed in order to improve output as postulated by Maumburudze (2016). For some, the number of bags consumed by the chickens did not tally with the number of chickens kept. For some it appeared to be guess work.

Further Expenses Incurred: Participants were asked to indicate further costs they incurred in rearing their indigenous chickens. Questions ranged from whether these rural women indigenous breeders had any helpers; the number of helpers, the activities the helpers performed and the labour costs incurred. Their responses are shown in Table 3.

Table 3: Shows Other Expenses Incurred by the Rural Women Indigenous Chicken Breeders

\begin{tabular}{|c|c|c|c|c|}
\hline Participant & Question 9 & Question 10 & Question 11 & Question 12 \\
\hline & $\begin{array}{l}\text { Do you have } \\
\text { any helpers? }\end{array}$ & $\begin{array}{l}\text { How many helpers } \\
\text { do you have? }\end{array}$ & $\begin{array}{l}\text { What activities do your } \\
\text { helpers do? }\end{array}$ & $\begin{array}{l}\text { How much do you pay } \\
\text { them? }\end{array}$ \\
\hline 1 & Yes & 3 & $\begin{array}{l}\text { 1) cleaning the fowl run } \\
\text { 2) giving chickens feed } \\
\text { 3) giving them water }\end{array}$ & I don't pay them. \\
\hline 2 & Yes & 3 & $\begin{array}{l}\text { 1)cleaning the fowl run } \\
\text { 2) giving them feeds } \\
\text { 3)giving them water } \\
\text { 4)locking them up in the } \\
\text { evening }\end{array}$ & $\begin{array}{l}\text { I don't pay them. We } \\
\text { share the spoils. }\end{array}$ \\
\hline 3 & No & $\mathrm{N} / \mathrm{A}$ & $\mathrm{N} / \mathrm{A}$ & $\mathrm{N} / \mathrm{A}$ \\
\hline 4 & Yes & 4 & $\begin{array}{l}\text { 1)cleaning the fowl run } \\
\text { 2)feeding the chickens }\end{array}$ & $\begin{array}{l}\text { They are my children. } \\
\text { I don't pay them. }\end{array}$ \\
\hline 5 & Yes & 3 & $\begin{array}{l}\text { watering and feeding the } \\
\text { chickens when I am not } \\
\text { around }\end{array}$ & $\begin{array}{l}\text { I provide for their } \\
\text { school needs because } \\
\text { they are my children. }\end{array}$ \\
\hline 6 & No & $\mathrm{N} / \mathrm{A}$ & I do it myself. & $\mathrm{N} / \mathrm{A}$ \\
\hline 7 & Yes & No & $\begin{array}{l}\text { I do all the activities } \\
\text { myself. }\end{array}$ & $\mathrm{N} / \mathrm{A}$ \\
\hline 8 & Yes & I & $\begin{array}{l}\text { cleaning the fowl run and } \\
\text { watering them }\end{array}$ & $\begin{array}{l}50 \text { RTGS. } \\
\text { Sometimes I buy him } \\
\text { groceries. }\end{array}$ \\
\hline 9 & No & $\mathrm{N} / \mathrm{A}$ & $\mathrm{N} / \mathrm{A}$ & $\mathrm{N} / \mathrm{A}$ \\
\hline 10 & Yes & 2 & $\begin{array}{l}\text { cleaning the fowl runs } \\
\text { and feeding them }\end{array}$ & $\begin{array}{l}\text { I pay fees for their } \\
\text { children. }\end{array}$ \\
\hline 11 & Yes & my 3 children & $\begin{array}{l}\text { cleaning the fowl run, } \\
\text { feeding and watering the } \\
\text { chickens }\end{array}$ & 30 RTGS \\
\hline 12 & Yes & One & feeding them & 30 RTGS \\
\hline 13 & No & N/A & N/A & $\mathrm{N} / \mathrm{A}$ \\
\hline 14 & No & $\begin{array}{l}\text { I do the work on } \\
\text { my own. }\end{array}$ & N/A & N/A \\
\hline 15 & No & $\begin{array}{l}\text { I do the work } \\
\text { myself. }\end{array}$ & $\mathrm{N} / \mathrm{A}$ & $\mathrm{N} / \mathrm{A}$ \\
\hline 16 & Yes & 2 & feeding the chickens & $\begin{array}{l}\text { I don't pay them. They } \\
\text { are my children. }\end{array}$ \\
\hline 17 & Yes & 1 & $\begin{array}{l}\text { cleaning the fowl run, } \\
\text { feeding and watering } \\
\text { them }\end{array}$ & $\begin{array}{l}30 \text { RTGS as and when I } \\
\text { get it. }\end{array}$ \\
\hline
\end{tabular}


What can be deduced from Table 3 is that participants in this study do not consider family labour to be 'paid labour.' This is evidenced from answers such as: Participant 1, "I don't pay them." Participant 2, "They are my children." These answers showed that the participants were ignorant of what constitutes costs of labour and that these costs should be incorporated in determining prices. Those who pay their helpers indicated that the money came from chicken sales.

Table 4: Shows Further Expenses and Proceeds

\begin{tabular}{|c|c|c|c|}
\hline Participant & Question 13 & Question 14 & Question 15 \\
\hline & $\begin{array}{l}\text { Are there any } \\
\text { other expenses } \\
\text { you incur for } \\
\text { your chickens? }\end{array}$ & What are these expenses? & Are you making any profit? \\
\hline 1 & Yes & Buying, them vaccines. & If the sales are good, I do. \\
\hline 2 & Yes & buying vaccines & Yes \\
\hline 3 & Yes & $\begin{array}{l}\text { buying vaccines eg terramycin } \\
\text { spray }\end{array}$ & Yes \\
\hline 4 & Yes & buying vaccines & Yes \\
\hline 5 & Yes & buying vaccines & a bit \\
\hline 6 & Yes & $\begin{array}{l}\text { Due to drought, I have to buy } \\
\text { water and it's } 10 \text { RTGS a } \\
\text { wheelbarrow. }\end{array}$ & a bit \\
\hline 7 & Yes & buying vaccines and net wire & No \\
\hline 8 & Yes & buying vaccines & a bit \\
\hline 9 & Yes & Antibiotics & Sometimes \\
\hline 10 & Yes & buying vaccines & Sometimes \\
\hline 11 & Yes & buying vaccines & A bit \\
\hline 12 & Yes & buying antibiotics & Yes \\
\hline 13 & Yes & buying vaccines & I used to, not anymore. \\
\hline 14 & Yes & buying vaccines & $\begin{array}{l}\text { I don't even know whether I am } \\
\text { making profit or not. }\end{array}$ \\
\hline 15 & Yes & vaccines & $\begin{array}{l}\text { I am not because I don't have } \\
\text { money to buy more chickens and } \\
\text { re-stock the feeds. }\end{array}$ \\
\hline 16 & Yes & vaccines & a little \\
\hline 17 & Yes & fuel for pumping the water & not much \\
\hline
\end{tabular}

Based on results in Table 4, rural women indigenous chicken breeders incur additional costs such as the purchase of vaccines. These results tally with the findings by Dube et al. (2016), that drugs and vaccines for poultry are expensive. This means that these are additional costs which women have to factor in but one wonders whether these expenses are taken into account when considering their prices. On the issue of whether they were making any profits, only four indicated that they were, with the rest saying that they were realising very little profit if any. Two participants were honest enough to say they no longer made any profits. Making profits is the fundamental reason for being in business. Participant 14," I don't even know whether I am making profit or not." Participant 15, "I am not, because I don't have money to buy more chickens and restock the feeds."

Challenges Faced by Rural Indigenous Poultry Breeders: In response to the question related to challenges faced by rural women indigenous poultry breeders, the following were given. 
Table 5: Shows Challenges Related to Price Determination

\begin{tabular}{|c|c|c|c|}
\hline Participant & Question 13 & Question 14 & Question 15 \\
\hline & $\begin{array}{l}\text { When you sell, how } \\
\text { much do you charge } \\
\text { per hen? }\end{array}$ & $\begin{array}{l}\text { When you } \\
\text { sell, how } \\
\text { much do you } \\
\text { charge per } \\
\text { cock? }\end{array}$ & $\begin{array}{l}\text { How do you determine the price for your hen or } \\
\text { chicken? }\end{array}$ \\
\hline 1 & 20 RTGS & 25 RTGS & $\begin{array}{l}\text { I consider weight. If the weight is low, I negotiate } \\
\text { with the buyer. }\end{array}$ \\
\hline 2 & 20 RTGS & 25 RTGS & $\begin{array}{l}\text { I only consider the number of chicks it has } \\
\text { produced for continuity purposes and I just } \\
\text { negotiate with the buyer. }\end{array}$ \\
\hline 3 & 20 RTGS & 25 RTGS & My labour and the costs of milling the feed. \\
\hline 4 & 20 RTGS & 25 RTGS & weight \\
\hline 5 & 20 RTGS & 25 RTGS & Amount of feed. Cocks eat more than hens. \\
\hline 6 & 20 RTGS & 25 RTGS & $\begin{array}{l}\text { I don't weigh them. I follow what the neighbours } \\
\text { are charging though sometimes I come up with my } \\
\text { own prices. }\end{array}$ \\
\hline 7 & 10 RTGS & 15 RTGS & weight \\
\hline 8 & 20 RTGS & 25 RTGS & The amount of time I take to rear them. \\
\hline 9 & 20 RTGS & 25RTGS & weight \\
\hline 10 & 50 RTGS & 60 RTGS & weight \\
\hline 11 & 50 RTGS & 60 RTGS & weight \\
\hline 12 & 55 RTGS & 60 RTGS & I consider their weight. \\
\hline 13 & 30 RTGS & 40 RTGS & I consider the weight \\
\hline 14 & 40 RTGS & 50 RTGS & Amount of feed \\
\hline 15 & 30 RTGS & 60 RTGS & weight \\
\hline 16 & 25 RTGS & 30 RTGS & I just sell. I don't consider anything. \\
\hline 17 & 30 RTGS & 40 RTGS & weight \\
\hline
\end{tabular}

Table 5 clearly shows that the prices charged are not market prices at all. One cannot even afford to buy supplementary feed with these incomes let alone improve their livelihoods. To make matters worse, participants indicated that they do not have scales with which to weigh their chickens in order to determine accurate prices. Determination of prices did not follow any formula as depicted by these verbatim statements. Participant 1, "I consider weight. If the weight is low, I negotiate with the buyer." Participant 6, "I don't weigh them. I just follow what the neighbours are charging." Participant 8, "I consider the time that I have taken to rear them." Participant 17, "I consider weight." Most of the participants said that they came up with prices of their chickens based on weight, or negotiation. However, there were others who said that they consider the time taken to rear the chickens or them just sell without any consideration.

Participants went further to say cocks were more expensive because they ate more than hens. Surprisingly, to gauge the weight of their chickens, they put them on the palms of their hands and shook them up and down. By so doing they said that they were able to feel the weight and tell which one weighed more and should be priced higher. This weight that is 'felt' does not consider input costs. It is just an approximation. Out of the 17 participants, there were three participants who said that they considered labour and amount of feed in determining prices as revealed in the statements that follow. Participant 3, "My labour and feeds." Participant 5, "Amount of feed. Cocks eat more than hens." Participant 14, "Amount of feed." To have only three knowledgeable people out of a total of 17 participants was really worrisome and called for speedy remediation. Regarding the challenges that they faced due to lack of knowledge on pricing, participants gave the answers reflected in Table 6. 


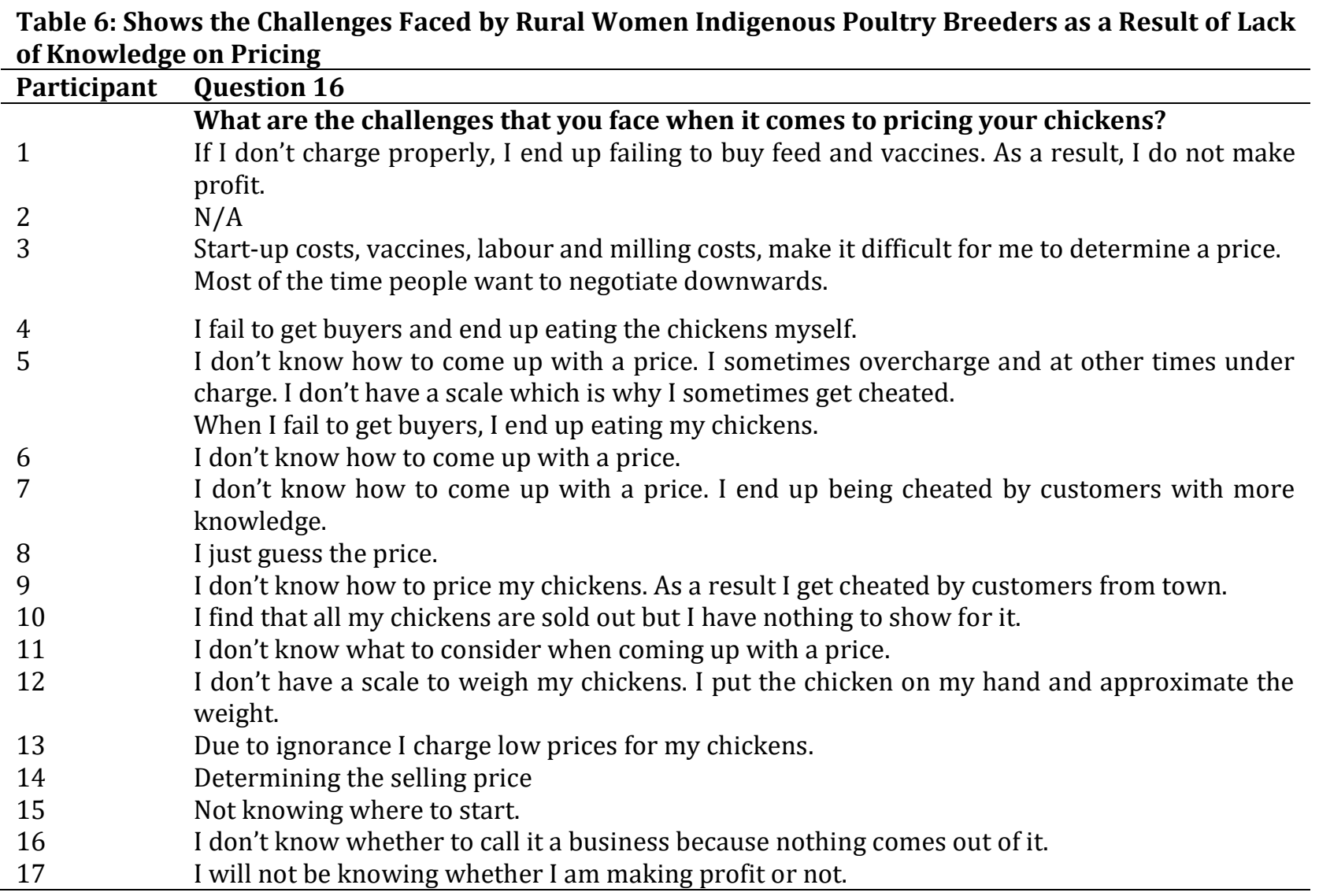

In Table 6, the majority of participants indicated that the major challenges that they faced bordered around lack of knowledge in determining prices. This is reflected in these statements. Participant 1, "If I don't charge properly, I end up failing to buy feed and vaccines. As a result, I do not make profit." Participant 5, "I don't know how to come up with a price. I sometimes overcharge and at other times under charge. I don't have a scale which is why I sometimes get cheated." Participant 7, "I don't know how to come up with a price. I end up being cheated by customers with more knowledge." What was clearly reflected by these findings was that rural women indigenous chicken breeders did not apply any pricing strategy because a profitable strategy would incorporate costs. A profitable pricing strategy would even factor in labour costs by their children as costs. This is why when deciding on the prices to charge, most of them indicated that they used weight because that is all that they knew. These findings are in tandem with observations by Zinyuke (2017) that the concept of commercialisation was fairly new. If there were to be buyers, knowledgeable about pricing strategies, these rural women indigenous chicken breeders would certainly lose out hence the need for a training programme to equip these women with requisite pricing strategies. The possible underlying contributory factor that can be deduced from these results is the lack of education by these rural indigenous chicken breeders (Kambarami, 2006).

Table 7: A Framework towards a Profitable Pricing Strategy for Rural Women Indigenous Chicken Breeders

\begin{tabular}{lll}
\hline Input Costs & Intervention Processes & Outcomes \\
\hline $\begin{array}{l}\text { Direct costs/expenses } \\
\text { cost of chicks (if applicable) }\end{array}$ & communication/ teaching & increased profits \\
stock feed & & $\begin{array}{l}\text { knowledge of pricing } \\
\text { reduced costs } \\
\text { vaccines }\end{array}$ \\
$\begin{array}{l}\text { Direct expenses } \\
\text { labour costs: } \\
\text { own labour }\end{array}$ & teamwork/communication & $\begin{array}{l}\text { good choice of labour } \\
\text { appropriate comparison of costs }\end{array}$ \\
\hline
\end{tabular}


casual labour (children and

helpers)

Variable overheads

Fixed costs

heat lamps

feeders

waterers

fencing

rented premises

Mark up- based on the market effective calculations

prices

Level of competition-consider teamwork

prices by competitors

Demand- If there is an increase in the numbers of chickens demanded, the price should be increased.

If there are too many chickens in the market, slightly reduce the price.

$$
\text { communication/teaching }
$$

communication

communication appropriate budgeting and analysis of overheads

fair allotment

As shown in Table 7, all these factors have to be incorporated when coming up with profitable prices for their indigenous chickens.

\section{Conclusion and Recommendations}

The study sought to find out the pricing strategies used by rural women indigenous chicken breeders in one selected village when determining prices for their chickens. Findings revealed that the participants lacked knowledge of factors to include when coming up with the prices. The study also showed that the selected rural women indigenous chicken breeders did not employ any pricing strategies when selling their chickens. They professed ignorance of the variables to be factored in when determining prices which include direct costs, direct expenses, variable and fixed overheads, mark up, the level of competition and demand. The study concluded that ignorance of the aforesaid input costs impacted negatively on their revenue and led to exploitation of these rural women indigenous chicken breeders by those knowledgeable on profitable pricing strategies. Based on the findings, the study made the following recommendations. To capacitate rural women indigenous chicken breeders on relevant pricing strategies, there is need for training on financial management skills. These workshops should be conducted by people with accounting skills who will carefully impart the requisite knowledge and skills of how to make calculations based on market prices. This would assist the rural women indigenous chicken breeders to identify their own direct and indirect costs and incorporate these costs in coming up with profitable prices.

Contribution of the Study to the Body of Knowledge: Results in this study glaringly show that coming up with a profitable pricing strategy for rural women indigenous chicken breeders is a big challenge, hence the need to develop a framework which rural women indigenous chicken breeders can use as a reference point when determining prices for their chickens. Based on literature search, this happens to be the first study that focused on developing a framework towards a profitable pricing strategy specifically for the selected rural village in Zimbabwe where this study was premised. Therefore, this study fills a gap in existing literature on the determination of an appropriate pricing strategy to benefit the rural women indigenous chicken breeders. The suggested framework shows the variables which rural women indigenous chicken breeders should include when determining a price. 
Areas for Further Research: The current study sought to find out the pricing strategies employed by rural women indigenous chicken breeders in one selected village in Zimbabwe. A further study could be conducted in an urban set up, with women who are now into rearing of indigenous chickens for comparative purposes, to find out what the situation is regarding the same phenomenon.

\section{References}

Alemayehu, T., Bruno, J., Getachew, F. \& Dessie, T. (2018). Socio-economic, marketing and gender aspects of village chicken production in the tropics. A review of literature. International Livestock Research Institute (ILRI) Colorado State University.

Cambridge Advanced Learner's Dictionary. (2008). $3^{\text {rd }}$ Edition, Cambridge University Press.

Cooper, D. R. \& Schindler. (2008). Business Research Methods. Singapore: McGraw-Hill/Irwin.

CSO (Central Statistical Office). (2002). Women and Men in Zimbabwe. Harare: Government printers.

Dube, M. H., Francis, J. \& Maliwichi, L. L. (2016). Poultry-based poverty alleviation projects in Ehlanzeni District Municipality: Do they contribute to the South African Government's 'Developmental State' ambition? South African Journal Agricultural Extension, 44 (2), 147-157.

Horngren, T. C., Foster, G. \& Datar, M. S. (1997). Cost Accounting- A managerial emphasis. Library of Congress Cataloging-in-Publication Data. USA Ninth Edition.

Kambarami, M. (2006). Femininity, Sexuality and Culture: Patriarchy and Female subordination in Zimbabwe. University of Fort Hare: Africa Regional Sexuality Resource Centre.

Kingori, A. M., Wachira, A. M. \& Tuitoek, K. J. (2010). Indigenous chicken production in Kenya: A review, International Journal of Poultry Science, 9(4), 309-316.

Mapiye, C., Mwale, M., Mupangwa, J. F., Chimonyo, M., Foti, R. \& Mutenje, M. J. (2008). A Research Review of Village Chicken Production Constraints and Opportunities in Zimbabwe. The Asian-Australasian Association of Animal Production Societies, 21(11), 1680-1688.

Maumburudze, D., Mutambara, J., Mugabe, P. \& Manyumwa, H. (2016). Prospects for commercialisation of indigenous chickens in Makoni District, Zimbabwe. Livestock Research for Rural Development, 28(4).

McAinsh, C. V., Kusina, J., Madsen, J. \& Nyoni, O. (2004). Traditional chicken production in Zimbabwe. World's Poultry Science Journal, 60(2), 233-246.

Mirembe, A. (2018). Determinants of Participation in the Indigenous Chicken Market by small holder farmers in Busia District, Eastern Uganda. Master of Science Thesis. Makerere University. November 2018.

Ouma, B. H. (2011). Factors influencing commercialisation of indigenous chicken in Njiru and Kasarani Districts in Nairobi County, Kenya. Master of Arts Dissertation. University of Nairobi.

Padhi, M. K. (2016). Importance of Indigenous Breeds of Chicken for rural economy and their improvements for higher production performance. Scientifica (Cairo)

Phiri, W. (2017). The Contribution of village chicken rearing to incomes of rural households: The case of Nyimba District in Eastern province. The International Journal of Multi-Disciplinary Research, 1-91.

Sichizuwe, S. S. (2019). The Contribution of Village Chickens to Household Income: A Case of farmers in Malimba of Kazungula District. ECRONICON Open Access EC Agriculture, 5.8(2019), 421-434.

Siyaya, B. J. (2013). Determinants of Profitability of Indigenous Chickens in Swaziland. Business and Economic Research, 3(2), 205-217.

TAN, D. H. Q. (2013). Understanding village poultry through the agricultural household model- A systematic literature review. Master's thesis, Uppsala.

Zinyuke, R. (2017). Free-range poultry production on the rise. https://www.chronicle.co.zw/free-rangepoultry-production-on-the-rise/. 